Ann. Biol. anim. Bioch. Biophys., 1978, 18 (1), 99-103.

\title{
Organic phosphorous distribution in chicken bone matrix
}

\author{
par Lola COHEN-SOLAL, M. J. GLIMCHER *
}

U. 18 INSERM, Hôpital Lariboisière, 6-8, rue Guy-Patin, 75010 Paris, France.

* Department of Orthopaedics, Children's Hospital Medical Center, 300 Longwood Avenue, Boston, Mass. 02115, USA.

Summary. Non-collagenous, soluble proteins and collagen have been extracted quantitatively from freshly dissected chicken bone at $4^{\circ} \mathrm{C}$ in presence of protease inhibitors, and their content in organic phosphorus assayed. We found that non-collagenous proteins were not covalently bound to collagen in chicken bone, as in some calcified tissues. They represented 30 p. 100 of the organic matrix and bound 75 p. 100 of the organic phosphorus. Collagen accounted for 70 p. 100 of the organic matrix and bound 25 p. 100 of the organic phosphorus. The presence of phosphate groups covalently linked to proteins in the bone matrix may play an important role as mineralization sites.

\section{Introduction.}

The mechanisms whereby mineral is deposited in certain collagenous tissues such as bone, dentin, calcified cartilage, but not in other connective tissues such as tendon and skin, are unknown. The cells or the organic matrix itself may play a catalytic role in the mineralization process.

Organic phosphate groups which have been identified in the proteins of calcified tissues could be important sites for the initiation of mineralization. Non-collagenous proteins have been identified in some calcified tissues such as enamel (Seyer ef al., 1971 ; Glimcher and Krane, 1964), dentin (Buttler, 1972) and bone (Shuttleworth et al., 1972) (Spector ef al., 1972). In some tissues only, these phosphoproteins have been found to be covalently bound to the collagen (Carmichael et al., 1971). This discrepancy may represent a species difference but also may be the result of the enzymatic cleavage of soluble phosphoproteins from collagen.

Although many studies on non-collagenous protein phosphorylation have been done and the presence of organic phosphorus on bone collagen defected (Glimcher et al., 1964), the quantitative distribution of the organic phosphorus covalently bound to the proteins of bone matrix, has never been established.

\section{Material and methods.}

The diaphyses of metatarsal bone of 10 -week old chickens were dissected immediately after slaughter. Two batches of bone were analyzed. For one batch protease 
inhibitors were added to all solutions : $0.1 \mathrm{mM}$-chloromercurylbenzoate, $10 \mu \mathrm{M}$ p-tolvene-sulfonylfluoride. The bones were scraped, washed in $1 \mathrm{M} \mathrm{NaCl}$ and $\mathrm{H}_{2} \mathrm{O}$ at $4{ }^{\circ} \mathrm{C}$, freeze-dried, and ground in a nitrogen mill. All the extractions were carried out at $4^{\circ} \mathrm{C}$.

1. Protein extraction and purification. Soluble non-collagenous proteins were extracted with $0.5 \mathrm{M}$ EDTA, pH 7.5 (Spector ef al., 1972). Subsequent analyses were performed on the crude EDTA soluble extract.

The collagen from the decalcified EDTA insoluble residue was extracted by

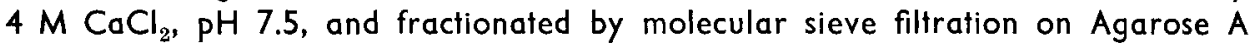
$15 \mathrm{M}(5 \times 180 \mathrm{~cm})$ eluted with $2 \mathrm{M} \mathrm{CaCl}_{2} 0.05 \mathrm{M}$ tris- $\mathrm{HCl}, \mathrm{pH} 7.5$. The alpha chains were further purified into alpha-1 and alpha-2 chains by ion-exchange chromatography on carboxymethylcellulose (Piez et al., 1963).

2. Analyfical determinations. The weight of organic components in native calcified bone was calculated from the weights of whole dry mineralized bone and ash. Protein concentrations were determined by amino acid analysis on a Beckman $121 \mathrm{M}$ amino acid analyzer. Collagen was assayed by hydroxyproline determination (Grant, 1964). Phosphorus was assayed according to the method of Chen et al., 1956. Organic phosphorus was obtained by deduction of inorganic phosphorus from the total phosphorus performed on a sample completely digested with 70 p. 100 perchloric acid. Phospholipid and nucleic acid extractions and their content in organic phosphorus were performed as described by Edelman et al. (1969).

TABLE 1

Compositions of cortical diaphyseal bone, organic non-diffusible components extracted in $0.5 \mathrm{M}$ EDTA, and EDTA insoluble decalcified residue (p. 100)

\begin{tabular}{|c|c|c|c|}
\hline & & $\begin{array}{l}\text { Protease } \\
\text { inhibitors present }\end{array}$ & $\begin{array}{c}\text { Protease } \\
\text { inhibitors absent }\end{array}$ \\
\hline Native dry bone & $\begin{array}{l}\text { Ash wt } \ldots \ldots \ldots \ldots \ldots \ldots \\
\text { Organic wt } \ldots \ldots \ldots \ldots \ldots \ldots \\
\text { Protein wt } \ldots \ldots \ldots \ldots \ldots \ldots \\
\text { Organic wt protein } \ldots \ldots \ldots \ldots\end{array}$ & $\begin{array}{l}65.9 \\
34.1 \\
24.8 \\
72.7\end{array}$ & \\
\hline $\begin{array}{l}\text { EDTA soluble, } \\
\text { non-diffusible } \\
\text { components }\end{array}$ & 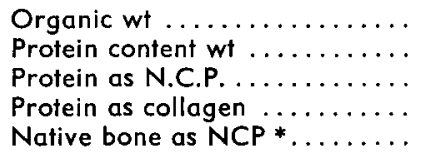 & $\begin{array}{c}30.5 \\
90.4 \\
100 \\
0.8 \\
7.6\end{array}$ & $\begin{array}{c}28.2 \\
92.1 \\
100 \\
0.6 \\
7.1\end{array}$ \\
\hline $\begin{array}{l}\text { EDTA insoluble } \\
\text { components }\end{array}$ & $\begin{array}{l}\text { Organic wt } \ldots \ldots \ldots \ldots \ldots \ldots \\
\text { Protein content wt } \ldots \ldots \ldots \ldots \ldots \\
\text { Protein as collagen } \ldots \ldots \ldots \ldots \\
\text { Native dry bone as collagen } \ldots\end{array}$ & $\begin{array}{c}69.5 \\
88 \\
100 \\
21.6\end{array}$ & $\begin{array}{l}71.8 \\
89 \\
100 \\
18.8\end{array}$ \\
\hline
\end{tabular}

* NCP : non-collagenous protein. 
cation of the collagen by gel filtration and separation of the alpha-1 and alpha-2 chains by ion-exchange chromatography, no nucleic acid was detected. The organic phosphorus distribution in chicken bone collagen is given in table 4 .

TABLE 4

Organic phosphorus in chicken bone collagen

\begin{tabular}{|c|c|}
\hline Collagen components & $\mathrm{P}$ atoms $/ 1000$ residues amino acids \\
\hline $\begin{array}{l}\text { Gamma-trimer } \ldots \ldots \ldots \ldots \ldots \ldots \\
\text { Bêta-trimer } \ldots \ldots \ldots \ldots \ldots \ldots \\
\text { Alpha-chains } \ldots \ldots \ldots \ldots \ldots \ldots \\
\text { Alpha } 1 \text {-chain } \ldots \ldots \ldots \ldots \ldots \ldots \\
\text { Alpha 2-chain } \ldots \ldots \ldots \ldots \ldots\end{array}$ & $\begin{array}{l}2.3 \\
2.2 \\
1.5 \\
0.3 \\
3.3\end{array}$ \\
\hline
\end{tabular}

\section{Discussion.}

Non-collagenous phosphoproteins present in the matrix of chicken bone can be extracted from freshly dissected bone in $0.5 \mathrm{M}$ EDTA at neutral $\mathrm{pH}$, even in the presence of inhibitors. Under these conditions, it is unlikely that the phosphoproteins are the result of proteolysis following slaughter of the animal and/or during subsequent extractions. It may be concluded that the soluble phosphoproteins of chicken bone are not covalently bound to collagen in vivo. These proteins represent about 25-30 p. 100 of the organic matrix proteins and they are highly phosphorylated. In addition to phosphate groups, they contain a high percentage of acidic amino acids such as aspartic acid, glutamic acid (Spector et al., 1972), gamma-dicarboxyglutamic acid (Hauschka ef al., 1975). Calcium ions could be very tightly linked to carboxyl groups and organic phosphate groups, to make a complex which would catalyse the initiation of mineralization.

Our results confirm earlier findings that the alpha chains of chicken bone contained covalently-bound organic phosphorus mainly located in the alpha-2 chain (François ef al., 1967). Although its phosphate content is low, its role in mineralization nucleation cannot be excluded.

Réunion Groupe Développement INRA/Productions animales Montpellier, 17-18 mai 1977.

Résumé. Les protéines solubles dans I'EDTA, de nature non collagénique, ainsi que le collagène ont été extraits à partir d'os diaphysaires de poulet, immédiatement après la mort des animaux. Les résultats obtenus dans les conditions de préparation choisies (tissu frais, basse température, présence d'inhibiteurs des enzymes protéolytiques) permettent de conclure que ces protéines ne sont pas liées covalentiellement au collagène. Bien que ces protéines ne présentent que 2.5 à 30 p. 100 des protéines de la matrice osseuse, leur taux en phosphate organique représente 70 à 75 p. 100 du phosphore organique total. La richesse en groupements phosphates associée à leur composition en acides aminés caractéristiques, confèrent à ces composés des propriétés importantes dans la liaison du calcium ef l'initiation possible de la minéralisation. Le collagène, environ 65 p. 100 des protéines, ne contient que 25 à 30 p. 100 du phosphore organique ; son rôle comme facteur d'initiation est également possible. 


\section{References}

BUTTLER W. T., 1972. Dentinal phosphoproteins, 255-262. In SLAVKIN H. C. The comparative molecular biology of exfracellular matrices, Acad. Press, Lond. and N. Y.

CARMICHAEL D. J., VEIS A., WANG E. T., 1971. Dentin matrix collagen : evidence for a covalently linked phosphoprotein attachment. Calcif. Tiss. Res., 7, 331-344.

CHEN P. S., Jr., TORIBARA T. Y., WARNER H., 1956. Microdetermination of phosphorus. Anal. Chem., 28, 1756-1758.

EDELMAN M., HIRSCH C. A., HIATT H. H., FOX M., 1969. Apparent changes in mouse liver DNA content due to interference by non-DNA diphenylamine-reacting cytoplasmic material. Biochim. biophys. Acta, 179, 172-178.

FRANÇOIS C. J., GLIMCHER M. J., 1967. Organic phosphorus content of the alpha chains of chicken bone collagen. Nature, 214, 621-622.

GLIMCHER M. J., FRANÇOIS C. J., RICHARDS L., KRANE S. M., 1964. The presence of organic phosphorus in collagens and gelatins. Biochim. biophys. Acta, 93, 585-602.

GLIMCHER M. J., KRANE S. M., 1964. The identification of serine phosphate in enamel proteins. Biochim. biophys. Acta, 90, 477-483.

GRANT R. A., 1964. Estimation of hydroxyproline by the auto analyser. J. clin. Path., 17, 685-686.

HAUSCHKA P. V., LIAN J. B., GALLOP P. M., 1975. Direct identification of the calcium-binding amino acid, gamma-carboxyglutamate, in mineralized tissue. Proc. nat. Acad. Sci., 72, 39253929.

PIEZ K. A., EIGNER E. A., LEWIS M. S., 1963. The chromatographic separation and amino acid composition of the subunits of several collagens. Biochemistry, 2, 58-66.

SEYER J. M., GLIMCHER M.J., 1971. The isolation of phosphorylated polypeptide components of the organic matrix of embryonic bovine enamel. Biochim. Biophys. Acia, 226, 279-291.

SPECTOR A. R., GLIMCHER M. J., 1972. The extraction and characterization of soluble anionic phosphoproteins from bone. Biochim. biophys. Acta, 263, 593-603.

SHUTTLEWORTH A., VEIS A., 1972. The isolation of anionic phosphoproteins from bovine cortical bone via the periodate solubilization of bone collagen. Biochim. biophys. Acta, 257, 414-420. 